History of Plant Virology: A Century of Developing a Discipline

Presented at the Annual Meeting of The American Phytopathological Society,

August 1, 2005, Austin, TX

\title{
Virus Design, 1955-1962: Science Meets Art
}

\author{
Gregory J. Morgan
}

Department of Philosophy, Spring Hill College, Mobile, AL 36608.

Accepted for publication 13 June 2006.

\begin{abstract}
Morgan, G. J. 2006. Virus design, 1955-1962: Science meets art. Phytopathology 96:1287-1291.

This paper traces the beginnings of structural virology in the mid-20th century, focusing especially on the synergy between models of virus structure and models within art, notably Buckminster Fuller's geodesic domes and Kenneth Snelson's tensegrity structures. As Donald Caspar and Aaron Klug sought to extend the Crick-Watson theory of spherical

virus structure, they explored analogies between biology and architecture, eventually publishing the classic Caspar-Klug theory of virus structure in 1962.

Additional keywords: fivefold symmetry, Francis Crick, James Watson, John McHale, Kenneth Snelson, Michael Goldberg, poliovirus, Rosalind Franklin, self-assembly, Tomato bushy stunt virus, triangulation number, Turnip yellow mosaic virus.
\end{abstract}

"I am always slightly surprised that people do not refer more to our ideas about virus structure," Francis Crick 1961.

The upcoming occasion of the 100th Anniversary of The American Phytopathological Society (APS) marks an opportune time to reflect on one of the more interesting episodes in the history of plant virology. Nearly 50 years ago, an unusual constellation of pioneers of modern molecular biology, unconventional artists, developments in biophysical techniques, and a focus on small plant viruses drove the then cutting-edge developments in the burgeoning field of structural biology. These early biologists looked outside of science for inspiration in interpreting their data and constructing many of the first detailed models of spherical virus structure. In particular, building upon the early theoretical work of Francis Crick and James Watson, Donald Caspar and Aaron Klug drew inspiration from Buckminster Fuller's geodesic domes and Kenneth Snelson's tensegrity sculptures. Caspar and Klug published their classic theory of virus structure in 1962 (6), but a natural place to begin the history of the episode occurs 7 years earlier.

In October-November 1955, structural virology took a significant step forward. The American biophysicist Donald Caspar began to examine x-ray diffraction patterns from single crystals of Tomato bushy stunt virus (TBSV) in Cambridge, England. Serendipitously, he had set his crystal close to a noncrystallographic fivefold rotation axis and obtained a decagonal diffraction pattern containing 10 maxima (Fig. 1). Further work showed spikes of intensity in the noncrystallographic fivefold directions. Caspar inferred that an icosahedral TBSV particle would generate such a pattern (3).

Corresponding author: G. J. Morgan; E-mail address: gmorgan@ shc.edu

DOI: 10.1094/PHYTO-96-1287

(c) 2006 The American Phytopathological Society
These exciting experimental results confirmed Crick and Watson's theoretical speculations about "spherical" viruses. Building on a suggestion of Dorothy Crowfoot Hodgkin's, they argued that spherical viruses must have cubic symmetry. Of the three types of cubic symmetry-icosahedral, octahedral, and tetrahedralCrick and Watson thought that icosahedral symmetry was most likely to occur because it allows a virus particle to consist of 60 identically situated asymmetric subunits and thus to enclose a larger volume of nucleic acid for a subunit of a particular size (7$9,17)$. Octahedral and tetrahedral symmetry allow only 24 and 12 asymmetric subunits, respectfully. (Hodgkin had argued that the number of subunits had to be a multiple of 12.) With the knowledge of Caspar's experimental results, Crick and Watson felt confident enough to publish their speculations. Their theory and Caspar's work on TBSV were published back-to-back in Nature in March $1956(3,8)$. In the same month, Crick presented these new ideas to a group of virologists at an important virology conference at the Ciba Foundation in London (32). In this "hazardous undertaking," he argued that for the majority of plant viruses and some animal viruses, such as poliovirus, the small amount of protein that can be coded by the small amount of RNA carried in each particle implies that the protein coat of the virus must consist of multiple copies of the same subunit protein. Crick referred to this proposal as a hazardous undertaking, in part, because in 1956 the existence of the genetic code based on three nucleotides for one amino acid was not generally accepted. Some in the audience, notably the Berkeley microscopist Robley Williams, remained skeptical of their speculative information-based reasoning.

In the discussion session following Crick's talk, Caspar presented ping-pong ball models to illustrate the cubic symmetry of spherical viruses. Aaron Klug reported that he and Rosalind Franklin's group had shown that Turnip yellow mosaic virus (TYMV) also appeared to have icosahedral symmetry $(21,22)$. The TYMV structure was proving to be a more difficult project than the TBSV structure-its crystal had a larger unit cell and, as 
Klug discovered, the virus particles crystallized in two distinct orientations. On the other hand, Roy Markham had isolated what appeared to be hollow shells of TYMV protein, i.e., empty virus particles (24), and Klug hoped that he would be able to compare Markham's "top component" with normal TYMV particles and infer properties of the TYMV RNA. Over the next 2 years, Aaron Klug and John Finch, working in Rosalind Franklin's laboratory, continued to pursue the TYMV structure (20). Her group also attempted to take the first diffraction pictures of poliovirus, but were hampered by the tendency of poliovirus crystals to dissolve

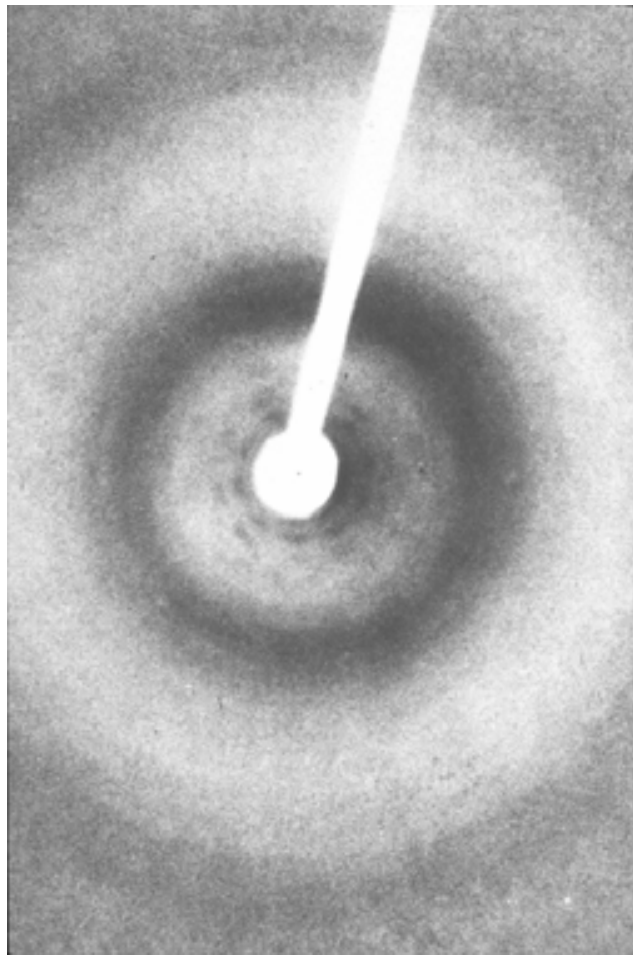

Fig. 1. Donald Caspar's unpublished $1955 \mathrm{x}$-ray diffraction pattern of a single crystal of Tomato bushy stunt virus. Reproduced with kind permission of Donald Caspar.

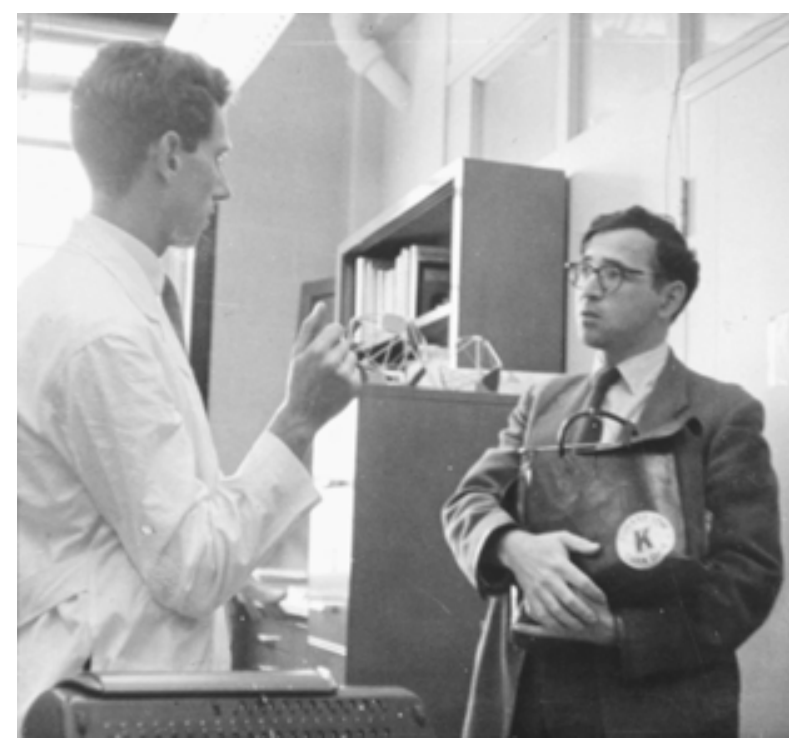

Fig. 2. Aaron Klug (right) and Kenneth Holmes (left) in Donald Caspar's office at the Children's Cancer Research Foundation in Boston in 1960. Holmes had completed his Ph.D. at Birkbeck College in Rosalind Franklin's group and was Caspar's first post-doc. Reproduced with kind permission of Donald Caspar. in glass capillaries. (Klug later discovered that quartz capillaries solved the problem.)

Caspar and Klug, although separated by the Atlantic, shared the goal of understanding the detailed structure of the small plant viruses. Tragedy brought them into collaboration (Fig. 2). APS celebrated its 50th anniversary in the late summer of 1958. APS had invited Rosalind Franklin to talk about her work on the structure of plant viruses. Although she knew she had cancer, Franklin had planned to give the talk, but sadly she succumbed to her illness in April. Her friend Caspar and her collaborator Klug agreed to present an article in her place. They wrote a review of the X-ray diffraction of viruses and added her name as a co-author $(11,19)$. In this review, they pointed out that biochemical data from the Berkeley Virus Laboratory suggested that TBSV had at least 120 chemical subunits. While this result did not refute the CrickWatson theory, it does suggest that there might be additional principles in the construction of spherical viruses.

Inspiration for new principles came through popularization of the proposed structure for poliovirus, which Finch and Klug published in 1959 (10). Advances in poliovirus research were newsworthy. The Manchester Guardian and The Observer published summaries of Klug and Finch's work. John McHale, a Londonbased artist, read about Klug and Finch's work and saw a possible connection with Buckminster Fuller's geodesic domes (Fig. 3). McHale popularized Fuller's ideas and later wrote one of the first books on Fuller's inventions (27). He arranged a meeting between the architect and the virologists. Unlike many scientists who would not take the time to penetrate the baroque vocabulary (18) of Fuller's "Synergetic Geometry" (12), Klug was more patient with the unconventional architect. Later Klug would be featured with Fuller in the debut episode of the BBC's Horizon series, "The World of Buckminster Fuller," which was broadcast in May 1964. Surprisingly, however, the initial meeting between Fuller and Klug did not lead to any new insights beyond the obvious observation that viruses and domes shared icosahedral symmetry. In April 1961, after Klug requested more details about the construction of geodesic domes, McHale sent Klug Fuller's unpublished manuscript "Energetic/Synergetic Geometry," which contained many images of geodesic domes. Some of these images suggested possible ways in which viral coat proteins could be arranged to make a capsid.

Why was an avant-garde artist interested in the connections between virology and architecture? John McHale was a member

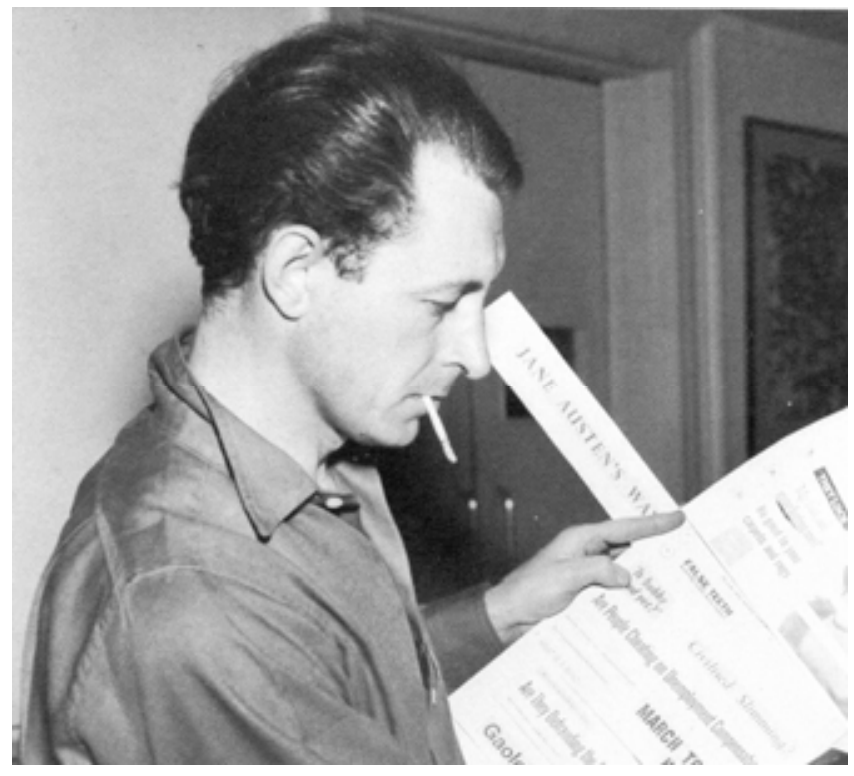

Fig. 3. John McHale in the 1950s. Used with kind permission of Magda McHale. 
of the "Independent Group," an influential rebellious group of artists who searched for new sources of aesthetic inspiration in popular culture, mass production, and science $(16,26)$. Other members of the group included Richard Hamilton, Eduardo Paolozzi, Reyner Banham, and Lawrence Alloway, who incidentally coined the term "pop art" (1). In 1951, they ran an exhibition, Growth and Form, that was inspired by the work of the biomathematician D'arcy Thompson (Fig. 4) (31). A second exhibition, Parallel of Life and Art, shown in 1953 also illustrates how the Independent Group looked to scientific images for aesthetic inspiration. In particular, McHale constructed a collage, Transistor (1954), to illustrate the theory of information developed by the mathematician/electrical engineer Claude Shannon. As a member of the Independent Group, McHale was primed to see connections between art and science.

In 1960, the first book on Buckminster Fuller was published (25). On separate sides of the Atlantic, Klug and Caspar read it and, more importantly, examined the images of geodesic domes as possible models for the arrangement of the subunits of viral shells. The radar geodesic domes or "radomes," which consisted of a number of hexagons and 12 pentagons, were suggestive. Caspar built his own models using building "toys" made by Geodestix of Spokane, WA. In 1962, Fuller was the Charles Eliot Norton professor of poetry at Harvard University. Caspar attended his lectures and spent many hours talking with him one-on-one in March 1962.

The image of the 270-strut tensegrity sphere was especially important for Klug (Fig. 5). Tensegrity structures were invented by the sculptor Kenneth Snelson (Fig. 6), although the term was coined by Buckminster Fuller $(12,18,30)$. Snelson defines

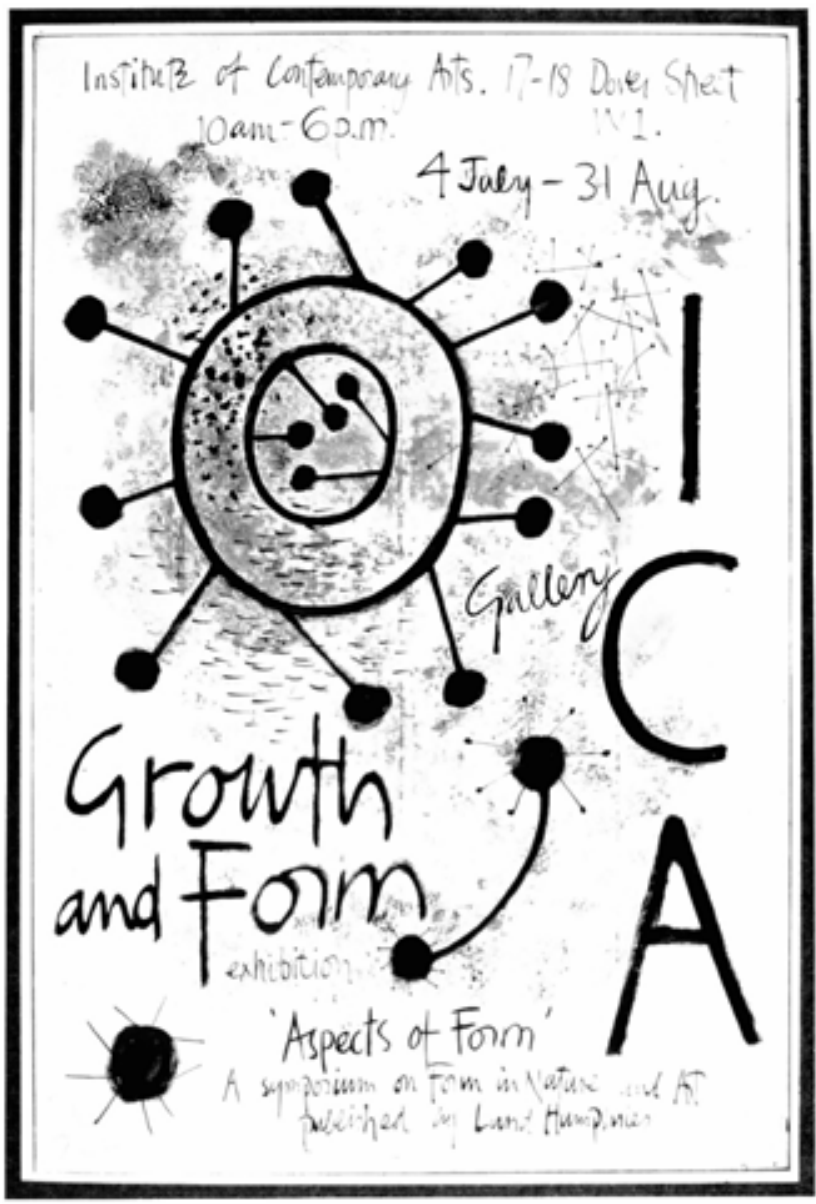

Fig. 4. Growth and Form exhibition poster. (C) 2005 Artists Rights Society (ARS), New York/DACS, London. tensegrity in the following way: "Tensegrity describes a closed structural system composed of a set of three or more elongate compression struts within a network of tension tendons, the combined parts mutually supportive in such a way that the struts do not touch one another, but press outwardly against nodal points in the tension network to form a firm, triangulated, prestressed, tension and compression unit" (http://www.kennethsnelson.net/ icons/struc.htm). Certain classes of tensegrity structures naturally

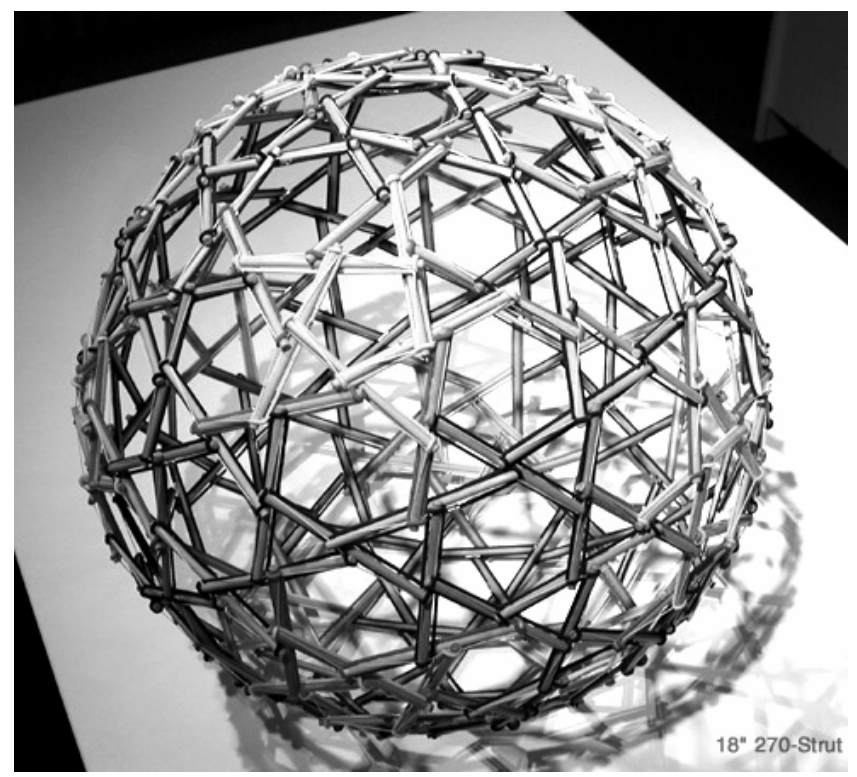

Fig. 5. A 270-strut tensegrity sphere. (C) $2000 \mathrm{Jim}$ Leftwich.

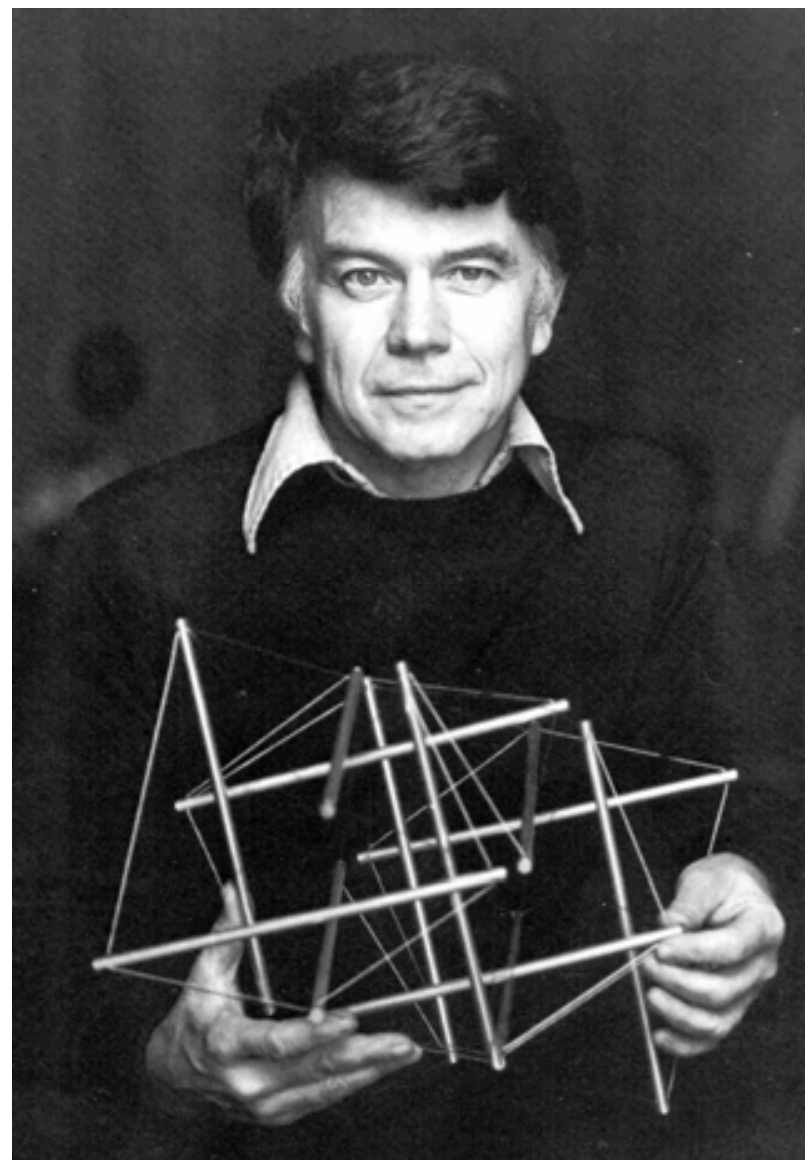

Fig. 6. Kenneth Snelson with a tensegrity model. Reproduced with kind permission of Kenneth Snelson. 


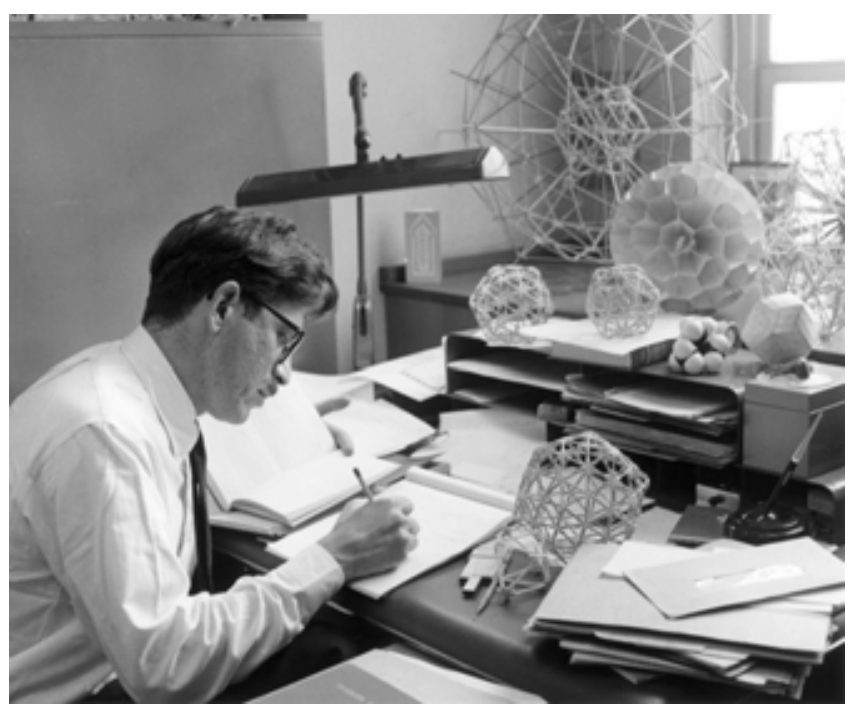

Fig. 7. Donald Caspar with his models. First published in The Boston Sunday Globe 7 April 1963. (C) 1963 Fred Clow.

arrange themselves into icosahedrally symmetric structures and resist deformation. This particular model is made from 270 building units or 540 asymmetric subunits because each strut can be divided into two identical asymmetric parts. The model provided an elegant solution to the problem of how to arrange 540 asymmetric protein units (9 multiples of 60) on the surface of a sphere. As Crick and Watson pointed out, it is geometrically impossible to arrange more than 60 identical asymmetric subunits on a sphere if all subunits are bonded together in exactly the same way. Klug mistakenly inferred that the 270 -strut tensegrity sphere was built from a single type of building unit with a certain amount of "give" in it. However, this notion of give evolved into Caspar and Klug's notion of "quasi-equivalence" $(23,28,29)$. As it turns out, Buckminster Fuller built the sphere from subtlety different types of building units: the lengths of the wires connecting the struts vary slightly depending on where the strut sits relative to the icosahedral symmetry axes. Nonetheless, this misprision, as Klug calls it following Caspar's college friend Harold Bloom's usage (2), opened up a new set of possibilities. If the bonding pattern among viral subunits is deformed only slightly, retaining the constraint that the bonding pattern among adjacent subunits is conserved, then shells with more than 60 subunits are geometrically possible. Partly due to Klug's reservations about the ambiguity in the term tensegrity and Caspar's desire to keep some material for a second theoretical article, Caspar and Klug did not refer to this concept in print. Although Caspar did eventually publish this idea 18 years later (4).

The concept of quasi-equivalence focused on the theoretical project of Caspar and Klug. Were there any general principles that governed icosahedrally symmetric quasi-equivalent structures? Crick and Watson suggested that the number of subunits on an icosahedrally symmetric structure would be a multiple of 60 . Assuming quasi-equivalent bonding, Caspar derived a formula that predicted which multiples of 60 would allow for the formation of icosahedrally symmetry structures: $T=k^{2}+h k+h^{2}$, where $h$ and $k$ are integers and $T$ is known as the triangulation number or $T$ number of the virus (Fig. 7). The equation is remarkably simple and was incorporated into the seminal paper that Caspar and Klug published in the 1962 Cold Spring Symposia volume (6). Using this formula, each virus can be classified by its $T$ number. For example, TBSV has a $T=3$ capsid. In many cases, if a virus capsid is made from one type of coat protein, then using electron microscopy, one can count the number of protein subunits on an icosahedral facet, the triangular space defined by three adjacent fivefold rotation axes. With some exceptions, such as polyoma-

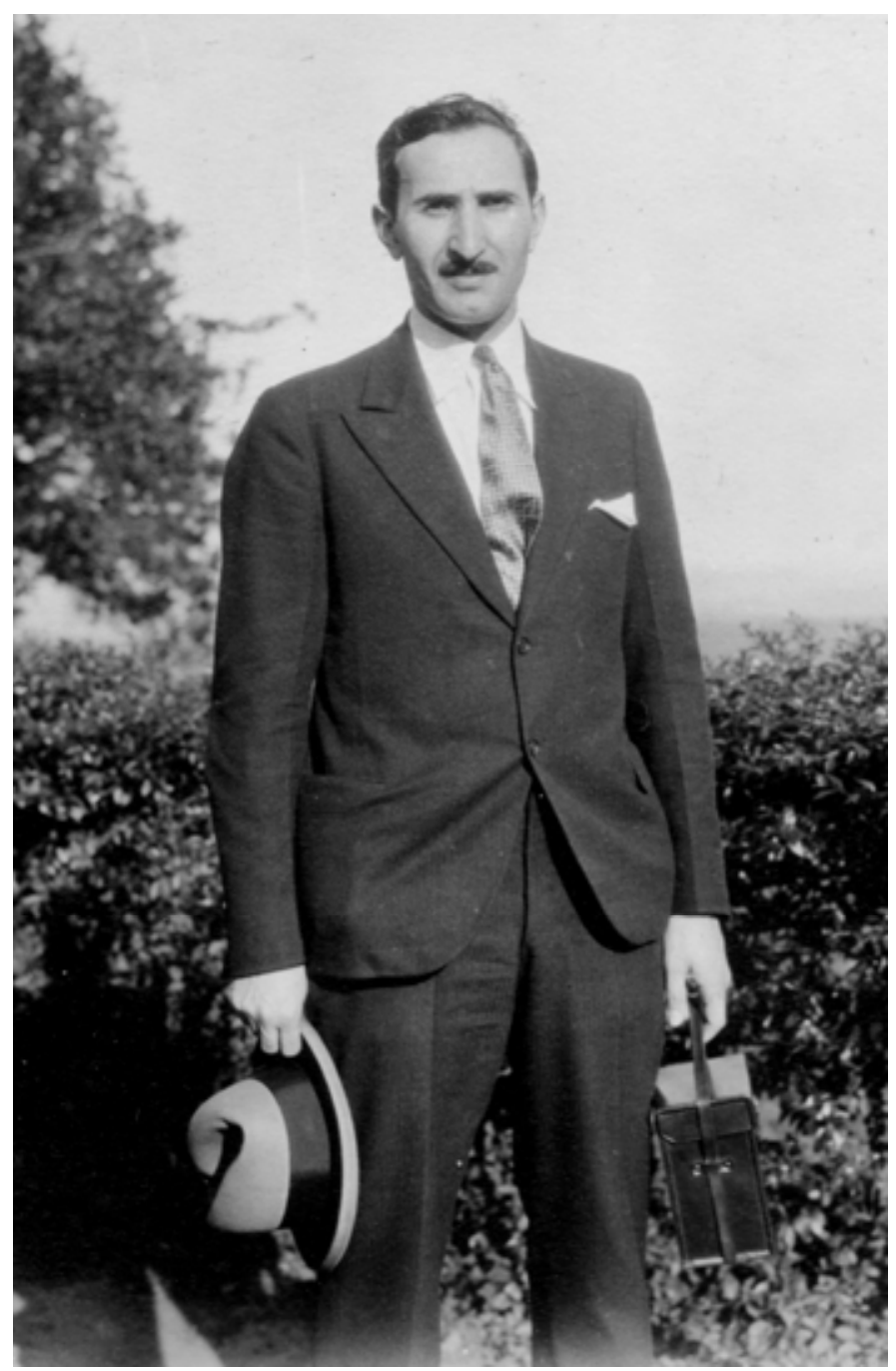

Fig. 8. Michael Goldberg in the 1930s. Reproduced with kind permission of Jeremy Goldberg.

virus, a spherical virus has $3 T$ subunits per facet. The classic paper by Caspar and Klug also explicitly introduced the term "self-assembly" into structural biology. This paper is now a citation classic with over 1,200 citations as of 2005 (5).

As is relatively common in the history of science, this story involves multiple discovery. As he learned a couple of years later, Caspar had rediscovered an equation that an amateur mathematician, Michael Goldberg, had published in an obscure Japanese mathematics journal in the 1930s (Fig. 8) (13-15). From a purely geometrical point of view, Goldberg considered properties of the medial polyhedra, those with trihedral vertices and only pentagonal and hexagonal faces. Beyond deriving the $T$ number equation, he was interested in how triangulation numbers were not topologically unique. For example, if $T=8,281$, there are multiple solutions: $k=91, h=0 ; k=85, h=11 ; k=80, k=19$; $k=65, h=39$; and $k=56, h=49$. However, this type of degeneracy has little biological relevance. Nonetheless, Caspar adapted one of Goldberg's figures of a hexagonal net into later presentations of the Caspar-Klug theory of virus structure, a theory that remains one of the simple, broad, and beautiful mathematical generalizations in biology.

\section{ACKNOWLEDGMENTS}

This paper was made possible by financial support from the NSF (award no. 9910891) and by a Spring Hill College Teagle research grant. I thank S. Welch, L. Darden, P. Achinstein, E. Lattman, M. Kemp, 
A. Creager, R. Olby, N. Comfort, S. Kingsland, and K. Snelson for useful comments; and the Jeremy Norman Archive, The Novartis Foundation, Stanford University Archives, LMB Cambridge Archive, Caltech Archives, Welcome Institute of Medicine, Royal Society Archives, UMBC Archives, Tate Gallery Archives, and the Churchill College Cambridge Archives for access to their material. Many people confirmed parts of this narrative. In particular, I thank E. Applewhite, S. Alloway, S. Brenner, C. Cohen, F. Crick, J. Finch, A. Gierer, J. Goldberg, K. Holmes, R. Horne, H. Huxley, R. Leberman, V. Luzzati, J. Maddox, L. Makowski, A. Massey, M. C. McHale, M. Perutz, A. Rich, K. Snelson, M. Stoker, J. Watson, and lastly, but certainly not least, D. Caspar and A. Klug.

\section{LITERATURE CITED}

1. Alloway, L. 1966. The development of British pop. Pages 27-68 in: Pop Art. L. Lippard, ed. Praeger Publishers, New York.

2. Bloom, H. 1973. The Anxiety of Influence. Oxford University Press, Oxford.

3. Caspar, D. L. D. 1956. Structure of bushy stunt virus. Nature 177:475.

4. Caspar, D. L. D. 1980. Movement and self-control in protein assemblies: Quasi-equivalence revisited. Biophys. J. 32:103-135.

5. Caspar, D. L. D. 1984. This Week's Citation Classic. Curr. Contents 27:15.

6. Caspar, D. L. D., and Klug, A. 1962. Physical principles in the construction of regular viruses. Cold Spring Harb. Sym. Quant. Biol. XXVII:1-24

7. Crick, F. H. C. 2003. Our work on virus structure. Pages 57-63 in: Inspiring Science: Jim Watson and the Age of DNA. J. Inglis, J. Sambrook, and J. Witkowski, eds. Cold Spring Harbor Laboratory, Cold Spring Harbor, NY.

8. Crick, F. H. C., and Watson, J. D. 1956. Structure of small viruses. Nature 177:473-475.

9. Crick, F. H. C., and Watson, J. D. 1957. Virus structure: General principles. Pages 5-13 in: CIBA Foundation Symposium on the Nature of Viruses. G. E. W. Wolstenholme, ed. Little Brown and Co., Boston.

10. Finch, J. T., and Klug, A. 1959. Structure of poliomyelitis virus. Nature 183:1709-1714.

11. Franklin, R., Caspar, D. L. D., and Klug, A. 1959. The structure of viruses as determined by $\mathrm{x}$-ray diffraction. Pages 5-13 in: Plant Pathology: Problems and Progress 1908-1958. University of Wisconsin Press, Madison.

12. Fuller, R. B., and Applewhite, E. J. 1975. Synergetics: Explorations in the Geometry of Thinking. Macmillan, New York.
13. Goldberg, M. 1934. The isoperimetric problem for polyhedra. Tôhoku Math. J. 40:226-236.

14. Goldberg, M. 1937. A class of multi-symmetric polyhedra. Tôhoku Math. J. 43:104-108.

15. Goldberg, M. 1980. A mathematical autobiography. Struct. Topol. 4:5760 .

16. Hamilton, R. 1984. Comments on McHale and his work. Pages $45-47$ in: The Expendable Icon: Works by John McHale. C. Kotik, ed. AlbrightKnox Gallery, Buffalo, NY.

17. Hodgkin, D. C. 1950. X-ray analysis and protein structure. Cold Spring Harb. Sym. Quant. Biol. 14:65-78.

18. Kenner, H. 1973. Bucky: A Guided Tour of Buckminster Fuller. William Morrow \& Co., New York.

19. Klug, A., and Caspar, D. L. D. 1960. The structure of small viruses. Adv. Virus Res. 7:225-325.

20. Klug, A., and Finch, J. T. 1960. The symmetries of the protein and nucleic acid in turnip yellow mosaic Virus: X-ray diffraction studies. J. Mol. Biol. 2:201-215

21. Klug, A., Finch, J. T., and Franklin, R. E. 1957. The structure of turnip yellow mosaic virus: X-ray studies. Biochim. Biophys. Acta 25:242-252.

22. Klug, A., Finch, J. T., and Franklin, R. E. 1957. Structure of turnip yellow virus. Nature 179:683-684.

23. Laszlo, P. 1986. The analogy between biomolecular structure and architecture. In: Molecular Correlates of Biological Concepts. P. Laszlo, ed. Elsevier Science Publications, Amsterdam.

24. Markham, R. 1951. Physiochemical studies of the turnip yellow mosaic virus. Discuss. Faraday Soc. 11:221

25. Marks, R. W. 1960. The Dymaxion World of Buckminster Fuller. Reinhold, New York.

26. Massey, A. 1995. The Independent Group: Modernism and Mass Culture in Britain. Manchester University Press, Manchester.

27. McHale, J. 1962. R. Buckminster Fuller. Brazillier, New York.

28. Morgan, G. J. 2003. Historical review: Viruses, crystals and geodesic domes. Trends Biochem. Sci. 28:86-91.

29. Morgan, G. J. 2004. Early theories of virus structure. Pages 1- 40 in: Conformational Proteomics of Macromolecular Architectures. H. Cheng and L. Hammar, eds. World Scientific, Singapore.

30. Snelson, K. 1981. Kenneth Snelson. Albright-Knox Art Gallery, Buffalo, NY.

31. Whyte, L. L. (ed.) 1951. Aspects of Form: A Symposium in Nature and Art. Lund Humphries, London.

32. Wolstenholme, G. E. W., and Millar, E. C. P. 1957. CIBA Foundation Symposium on the Nature of Viruses. Little Brown and Co., Boston. 